\title{
Evaluation of Photosynthetic Capacity and Grain Yield of the Sea Level Quinoa Variety Titicaca Grown in a Highland Region of Northwest Argentine
}

\author{
Juan A. González ${ }^{1}$, Sven E. Jacobsen ${ }^{2}$, Sebastián E. Buedo ${ }^{1}$, Luis E. Erazzú ${ }^{3}$, Daniela A. \\ González ${ }^{4}$ and Fernando E. Prado ${ }^{4}$
}

\author{
${ }^{1}$ Fundación Miguel Lillo, Instituto de Ecología, Miguel Lillo 251, 4000 Tucumán, Argentina. \\ ${ }^{2}$ Quinoa Quality ApS - CVR 40610588- Teglvarksvej 10- DK-4420 Regstrup - Denmark. \\ www.quinoaquality.com \\ ${ }^{3}$ Instituto Nacional de Tecnología Agropecuaria (INTA), Famaillá, Tucumán, Argentina. Facultad de \\ Agronomía y Zooctenia, Universidad Nacional de Tucumán, Avda. Roca 1900, 4000 Tucumán, \\ Argentina. \\ ${ }^{4}$ Instituto de Bioprospección y Fisiología Vegetal (INBIOFIV), CONICET - UNT. Cátedra de Fisiología \\ Vegetal, Facultad de Ciencias Naturales e IML, Universidad Nacional de Tucumán, Miguel Lillo 205, \\ 4000 Tucumán, Argentina.
}

Received: 11 Sept. 2019 / Accepted 10 Oct. 2019 / Publication date: 20 Oct. 2019

\begin{abstract}
Photosynthetic characterization of the quinoa cultivar Titicaca grown at the Encalilla site (1995 $m$ asl), a high mountain valley of the Argentinean Northwest, is described in this study. Titicaca cultivar, bred in Denmark from Chilean and Peruvian parenteral lines, is a promising short cycle cultivar and daylength neutral photoperiod. Results showed that maximal photosynthetic $\mathrm{CO}_{2}$ assimilation $\left(\mathrm{A}_{\max }\right)$ and stomatal conductance $\left(\mathrm{g}_{\mathrm{s}}\right)$ were similar to other quinoa varieties. However, carboxilation capacity and leaf transpiration (E) were significantly higher in Titicaca cultivar compared with other quinoa cultivars grown in the same place. Assimilation of $\mathrm{CO}_{2}$ and stomatal conductance exhibited a strong correlation, like that occurs between (E) and $\left(\mathrm{g}_{\mathrm{s}}\right)$. Light saturation point (LSP) and light compensation point (LCP) were higher in relation to other quinoa cultivars. Grain yield of 2.35 and $2.51 \mathrm{~g} / \mathrm{plant}$ was recorded and indicating a well adaptation to arid climatic conditions of the Argentinean Northwest region. The highest value of UV protective pigments found in Titicaca will be explained by solar irradiance in the grown area in relation to Denmark conditions. Grain yield, harvest index and some physiological parameters suggested a good adaptation of the Titicaca quinoa cultivar to high mountain valleys of the Argentina Northwest. This means that Titicaca may be considered as a good alternative for farmers in order to get similar production in less time.
\end{abstract}

Keywords: Chenopodium quinoa, Adaptation, Grain yield, Transpiration, Carboxylation, Pigments.

\section{Introduction}

Quinoa was originated in a Titikaka lake area (between Bolivia and Perú at 3,800 m asl) (Rojas et al., 2015). Owing to quinoa is highly tolerant to weather harsh conditions and for its high adaptability to different geographical diversity, it was able to spread to lowland and high mountain of Ecuador, Perú, Bolivia and Northwest Argentine. Agriculture in highland is characterized by a high degree of risk due to drought, frost, wind, hail, soil salinity (Jacobsen, 2003) and high radiation (Hilal et al., 2004; González et al., 2009). Among problems for plant food production in the Andes mountains those related to water shortage are stand out. In effect, low rainfall, high evapotranspiration rate and low soil capacity retention are prevalent edaphological traits in highland of Andean regions. Among scarce crops able to develop in extreme dry conditions, the quinoa can tolerate all these constraints and also produce a highly nutritious grain with all essential amino acids, compare to our current cereals (González et al., 2011). Because the quinoa grain meets and surpasses recommended nutritional requirements by the World Health Organization (WHO) (Repo-Carrasco et al., 2003), quinoa is well known now as a new promising crop species for food security (Mujica et al., 2001; Jacobsen et al., 2013) around the world (Bazile and Baudron, 2015) and for different climatic change scenarios (González et al., 2015; Jacobsen et al., 2015). Due to the higher nutritional values and tolerance to stresful conditions, quinoa was 
revived as a new food crop and are being cultivated outside the Andean region (eg. USA, Europe, Africa, India and China) (Bazile and Baudron, 2015). According to recent data (Quinoa International Congress, Puno, Perú, 2017) at least 110 countries has quinoa trials and some of them are trying and getting new varieties adapted to their preveling climatic and soil conditions. In Argentina, the first area for quinoa cultivation is located in the Northwest mountain area (Salta, Jujuy, Catamarca and Tucumán provinces). The first attempt to re-introduce quinoa in these areas was in 1984 and the second ones in 1996 (American and European Test of Quinoa) in which at least 25 varieties were used. The majority of the used varieties belong to long growth cycles (up to 140 days) group. Presently farmers use long growth cycles varieties (up to 140 days) and specially CICA variety from Perú. Of course, the long growth cycles varieties need more water for irrigation and different farming practices. All of these were cost and time effective. In Argentina mountain area quinoa sowing takes place in November and is harvested in April or May. In this period there is a wet time (summer, from December to March) and a dry one (from April to September). One problem with CICA cultivation, or other long cycle ones, is the concurrence of the dry period (autumn) with the grain filling stage. In this sense, and to preserve soil and save water, that is scarce in all the high mountain places, it is desirable to get a short growth cycle variety. Therefore, the use of short growth cycle variety has a desirable advantage. In this context, the Titicaca variety, breds in Denmark from Chilean and Peruvian parenteral lines, is a short growth cycle cultivar, matures early and neutral photoperiod response (Christiansen et al., 2010) should be a good alternative for Argentine's highland. Presently Titicaca is cultivated in Europe (Denmark, Italy) and some countries of the Middle East and North Africa (MENA), but not in South America. In order to get new possibilities for a food crop in the Northwest mountaineous region of the Argentina, we performed an ecophysiological evaluation in the field of the Titicaca variety. There are large differences in the yields of crops between and within various countries and world's regions. These differences are caused by a variety of factors including the natural environment, management practices, cultivars and/or varieties, access to water, irrigation, fertilizers, pesticides, and other inputs (Van Wart et al., 2013). So, the aim of this study was to evaluate Titicaca in field conditions in term of gas exchange parameters, carboxilation capacity, water use efficiency, photosynthetic pigments concentration and yield components grown in a semiarid mountainous region of Northwest Argentine. Data can represent an important tool to evaluate new cultivars and especially the control of $\mathrm{H}_{2} \mathrm{O} / \mathrm{CO}_{2}$ exchange that is crucial for plant growth and biomass production under stressful conditions (Gulzar et al., 2005).

\section{Materials and Methods}

\section{Plant material and sowing}

Titicaca seeds were obtained from the University of Copenhagen (Taastrup, $55^{\circ} 40^{\prime} \mathrm{N} ; 2^{\circ} 18^{\prime}$ E, $28 \mathrm{~m}$ asl, Copenhagen, Denmark). Titicaca is a pure line bred in Denmark, characterized for an early maturity and neutral photoperiod response (Christiansen et al., 2010). Field trials were conducted during November to February of $2014-2015$ and 2015 - 2016 in an arid mountain region of the Argentina Northwest (Encalilla, Amaicha del Valle, 22 ${ }^{\circ} 31^{\prime} \mathrm{S}, 65^{\circ} 59^{\prime} \mathrm{W}, 1995 \mathrm{~m}$ asl, Tucumán, Argentina). The soil of Encalilla site is sandy loam clay classified as Xeric Torriorthent type according to the FAO/UNESCO soil taxonomy (Batjes, 1997). Physicochemical parameters of Encalilla soil at $0.5 \mathrm{~m}$ depth were: $\mathrm{pH} 8.8$, organic matter content $0.6 \%$, total nitrogen $0.55 \%$, and EC $2 \mathrm{dS} \mathrm{m}^{-1}$ (González et al., 2010). Climatic characteristics of the Encalilla site are typical of the high mountain valleys in the Argentina Northwest, which is characterized by a low rainfall with an annual mean value of $160 \mathrm{~mm}$ for the last 32 years. Near $90 \%$ of the total rainfall occurred during the growing season (September to February). Soil evapotranspiration calculated with the Penman-Monteith equation was $420 \mathrm{~mm}$. In general, Encalilla climate has been classified as an arid environment with cold winters and hot summers. Meteorogical data are summarized in table below and represent mean of November to February of 2014 - 2015 and $2015-2016$

Meteorogical data for the grown period (Encalilla site, Tucumán, Argentina

\begin{tabular}{llll}
\hline Maximal Temperature $\left({ }^{\circ} \mathrm{C}\right)$ & $30.5 \pm 1.7$ & Minimal Temperature $\left({ }^{\circ} \mathrm{C}\right)$ & $9.7 \pm 1.3^{\circ}$ \\
Wind velocity $(\mathrm{km} / \mathrm{h})$ & 8 to 16 & $\mathrm{RH}(\%)$ & $58.1 \pm 3.1$ \\
PAR $\left(\mu \mathrm{mol} \mathrm{m} \mathrm{s}^{-2}\right)$ & $1.893 \pm 46$ & & \\
\hline
\end{tabular}


Minimum and maximum air temperatures, relative humidity and wind velocity were recorded using different sensors coupled to an automatic weather station (Pegasus EP1000, Argentina). PAR radiation was recorded over 1:30 pm during the growing season. PAR radiation was measured with a quantum sensor (LI-190S coupled to LI-1400 data logger, LI-COR, U.S.A.).

Seeds were sown on the middle of November 2014 and 2015. Each plot $(10 \times 5 \mathrm{~m})$ had five rows ( $5 \mathrm{~m}$ long), $10 \mathrm{~cm}$ interplant spacing and $50 \mathrm{~cm}$ between rows with $\mathrm{N}-\mathrm{S}$ direction. Seedbed preparation was carried out just prior to sowing by harrowing with a hand garden plow machine. Plots were irrigated by direct irrigation equivalent to $10 \mathrm{~mm}$ rainfall one day prior to sowing the seeds. Seeds were sown at $2-3 \mathrm{~cm}$ depth in $10 \mathrm{~cm}$ spaced holes (5 - 10 seeds for each hole). When seedlings had four leaves, a hand-thinning was carried out to get a plant density of 80,000 plants $\mathrm{ha}^{-1}$. Along the cropping cycle, furrows were irrigated weekly in the morning to get a soil water profile of about $200 \mathrm{~mm} /$ year for the whole cultivation period at the end of the experiment. No additional fertilization and no control of fungal diseases and pests were carried out during the cropping cycle. During the growing cycle, interrow weed control was made by hand.

\section{Gas exchange measurements}

Gas exchange measurements were performed during January month in sunny days only using an open infrared gas-exchange system (IRGA) equipped with a fluorometer chamber (LI-COR 6400 XT, LI-COR, Lincoln, NE, USA). Measurements were carried out at 65 - 70 DAYS (days after sowing) just to beginning of flowering stage (between $20-25$ Jannuary). Twelve hours prior to gas exchange measurements all plots were irrigated. Photosynthetic light response curves $\left(\mathrm{A}_{\mathrm{n}} / \mathrm{PPFD}\right.$ curves $)$ were performed on the third uppermost fully expanded leaf exposed to light source ( $10 \%$ blue and $90 \%$ red) provided by the LI-COR equipment. Photosynthetic photon flux densities (PPFD) ranged between 0 and $2,000 \mu \mathrm{mol} \mathrm{m} \mathrm{m}^{-2} \mathrm{~s}^{-1}$ were used. Net $\mathrm{CO}_{2}$ assimilation rate $\left(\mathrm{A}_{\mathrm{n}}\right)$, transpiration rate $(\mathrm{E})$, and stomatal to conductance $\left(\mathrm{g}_{\mathrm{s}}\right)$ were measured at $1,500 \mu \mathrm{mol} \mathrm{m} \mathrm{m}^{-2} \mathrm{~s}^{-1}$ after a 3-5 min acclimation period. All measurements were made at a relative humidity of $50-60 \%$, leaf temperature of $25 \pm 1{ }^{\circ} \mathrm{C}$, air flow rate of $300 \mu \mathrm{mol} \mathrm{s}^{-1}$ and $400 \mu \mathrm{mol} \mathrm{mol}^{-1} \mathrm{CO}_{2}$ concentration inside the leaf chamber. Each measurement was repeated until obtain at least three stable values. All measurements were made from 09:00 to 13:00 am). The carboxylation capacity and maximum carboxylation capacity were expressed as $A_{n} / C_{i}$ and $\mathrm{A}_{\max } / \mathrm{C}_{\mathrm{i}}$ ratios whereas the instantaneous water use efficiency (iWUE) was calculated as $\mathrm{A}_{\max } / \mathrm{g}_{\mathrm{s}}$ ratio (Rawson et al., 1977). Photosynthetic light response curves were used to calculate theoretical maximal photosynthetic rate $\left(\mathrm{A}_{\max }\right)$, light compensation point (LCP), light saturation point (LSP), dark respiration rate $\left(\mathrm{R}_{\mathrm{d}}\right)$ and apparent quantum yield of photosynthetic $\mathrm{CO}_{2}$ assimilation $\left(\Phi_{\mathrm{CO} 2}\right)$ (Schulte et al., 2003). Chlorophyll fluorescence measurements were carried out to quantify the light-adapted quantum efficiency of photosystem II ( $\Phi_{\text {PSII }}$ (Genty et al., 1989). Electron transport rate (ETR) was calculated according to Schreiber et al. (1986) by using the formula:

$$
\mathrm{ETR}=\text { ФPSII } * \text { PPFD } * 0.5 * 0.84
$$

Photosynthesis responses to internal leaf $\mathrm{CO}_{2}$ concentrations $\left(\mathrm{A}_{\mathrm{n}} / \mathrm{C}_{\mathrm{i}}\right.$ curves $)$ were determined at $1500 \mu \mathrm{mol} \mathrm{m} \mathrm{m}^{-2} \mathrm{~s}^{-1}$ of PPFD. We set the $\mathrm{CO}_{2}$ response curve autoprogram with minimum and maximum wait times of 120 and $180 \mathrm{~s}$, respectively. The IRGA equipment was matched at every $\mathrm{CO}_{2}$ concentration. Values of $\mathrm{CO}_{2}$ reference between 50 and $2,000 \mu \mathrm{mol} \mathrm{mol}^{-1}$ and airflow rate of $500 \mu \mathrm{mol}$ $\mathrm{s}^{-1}$ were used. $\mathrm{A}_{\mathrm{n}} / \mathrm{C}_{\mathrm{i}}$ curves were used to calculate the carboxylation efficiency according to Farquhar and Sharkey (1982). Both $\mathrm{CO}_{2}$ saturation point (SP) and $\mathrm{CO}_{2}$ compensation point (CP) were calculated using exponential functions described by Schulte et al. (2003).

\section{Pigments content}

Plants used for gas exchange measurements were also used to determine both photosynthetic and UV-B absorbing pigments. Chlorophyll and carotenoids were extracted using dimethyl sulfoxide during $12 \mathrm{~h}$ in darkness at $45^{\circ} \mathrm{C}$, as described by Chapelle et al. (1992). Chlorophyll $a, b$ and carotenoids contents were calculated from absorbances at 649,665 and $480 \mathrm{~nm}$ according to Wellburn's procedure (1994) and expressed as $\mathrm{mg} / \mathrm{g}$ DW. UV-B absorbing compounds were extracted using acidified metanol/water/HCl, 79:20:1 according to the procedure of Mirecki and Teramura (1984) determined spectrophotometrically at $305 \mathrm{~nm}$ and expressed as $\mathrm{A}_{305} \mathrm{mg}^{-1} \mathrm{DW}$. 


\section{Biomass production and grain yield}

At physiological maturity, defined as the date when seeds from the main panicle become resistant when pressed, plants from the five central rows were hand-harvested and the height and stem diameter were measured. Grain panicles (main and secondary panicles) were cut and sun-dried to obtain seeds and bracts. The rest of plant was divided into roots and stems to determine dry weight (DW). To determine DW, plant parts were oven dried at $80^{\circ} \mathrm{C}$ for $60 \mathrm{~h}$ till constant weight. Grain yield and 1000 seed weight were also determined. Harvest index (HI) was calculated as the ratio between grain yield and total above-ground biomass.

\section{Statistical analysis}

Data were analyzed using a one-way ANOVA and statistical package SPSS, version 11.0. The treatment mean values were compared by Duncan's Multiple Range Test at $p \leq 0.05$ level of probability (Duncan, 1955).

\section{Results and Discussion}

Because there were no large differences in environmental conditions data of gas exchange parameters reported in this study correspond to the average of the two years.

\section{Titicaca development and cropping cycle}

Titicaca completed their development cycle 96 and 99 DAS for 2015 and 2016, respectively. These cycles were a few days shorter than those reported by Jacobsen et al. (2010) and Pulvento et al. (2012) for quinoa trials in European countries. The use of short growth cycle quinoa cultivars is not a common practice among South American farmers. In Perú Gómez-Pando et al. (2010) reported that 15 accesions with life cycles between 150 and 200 DAS are currently used by local farmers, while Rojas et al. (2015) reported a mean of 177 DAS for the life cycle of the Bolivian quinoa germplasm. In Argentinean Northwest the quinoa's farmers used long growth cycle cultivars (approximately 150 DAS) such as CICA, Amarilla de Maranganí or Relagona Baer. Shorter cropping cycles implie less soil occupation, less agricultural pratices and less water comsumption, which could be an interesting economic advantage for peoples of the mountaneous region of Argentina Northwest. Moreover, the use of short cycle cultivars opens the possibility to perform two crops per year (September - December and December - March) not only in the Northwestern Argentina but also in many other South American places. This hypothesis should be supported with future trials.

\section{Grain yield and growth parameters}

In the two years, there were no significant differences in grain yield, panicle weight and stem diameter. Grain yield of 2.35 and $2.51 \mathrm{~g} /$ plant were recorded in both cropping cycles (Table 1). For the Titicaca cultivar, Yang et al. (2016) reported a value of $13 \mathrm{~g} / \mathrm{plant}$ in pot experiment, while Shams (2012) reported a value between 0.783 and $0.867 \mathrm{~g} /$ plant in sandy soil. It is interesting to point out that the Titicaca grain yield obtained in Encalilla was close to those reported for long cycles varieties presently cultivated in Northwest Argentine (1.8 to $3.5 \mathrm{~g} / \mathrm{plant}$ ) (Curti et al., 2014). On the other hand, Gómez-Pando et al. (2010) reported a range between 1-10 g/plant for 15 different genotypes from Puno (Perú) while Delgado et al. (2009) reported values of 2.5 to $3.4 \mathrm{~g} / \mathrm{plant}$ for 16 quinoa genotypes cultivated in the region of Nariño (Colombia). Average grain yield obtained in Encalilla will be indicating a well adaptation to arid climatic conditions of the Argentinean Northwest region.

Value of the 1000 seed weight found at Encalilla site were 2.41 and $2.59 \mathrm{~g} \mathrm{(2014-2015}$ and 20152016, respectively), but there no signficant difference between years was realized (Table 1). These values were similar to others reported previously in Italy (Pulvento et al., 2012), Denmark (Yang et al., 2016) and Turkey (Kir and Temel, 2016). But were significant different to values of 0.28 to $1.10 \mathrm{~g}$ recently reported for the Titicaca cultivar grown in and altitudinal trials in Malawi (Maliro et al., 2017). According to the findings of Maliro et al. (2017) the 1000 seed weight parameter of Titicaca cultivar seems to be directly correlated with temperature and precipitation when grows in altitudinal gradients.

Plant height is another important growth parameter because an ideal quinoa plant must not be very tall to avoid the wind influence and if it is possible unbranched to facilitate the harvest process (handmade or mechanical). Plant height charcter achieved in Encalilla (Table 1) was located among 
others reported for Titicaca in other places in a world. Values ranging between 49.3 and $140.6 \mathrm{~cm}$ have been communicated for the Titicaca cultivar growing under both controlled and field conditions (Adolf et al., 2012; Yang et al., 2016; Yazar et al., 2016). Regarding stem diameter character, it showed no significant differences in both crop cycles.

Our results obtained in Encalilla site were agreed with the current knowledge for grain yield and growth parameters of different quinoa cultivars, or varieties, however, those were quite variable among different countries and even among regions of the same country (Lavini et al., 2014).

Table 1: Yield components of the Titicaca cultivar corresponding to 2014-2015 and 2015-2016 cropping cycles. Data are means \pm SE of 15 different plants. Means followed by the same letter within a column are not significantly different at $\mathrm{p} \leq 0.05$.

\begin{tabular}{cccccc}
\hline $\begin{array}{c}\text { Cropping } \\
\text { Cycle }\end{array}$ & $\begin{array}{c}\text { Grain yield } \\
\text { (g/plant) }\end{array}$ & $\begin{array}{c}\text { Panicle weight } \\
\text { (g/plant*) }\end{array}$ & $\begin{array}{c}\text { 1000 grain } \\
\text { weight }(\mathbf{g})\end{array}$ & $\begin{array}{c}\text { Plant height } \\
\text { (cm) }\end{array}$ & $\begin{array}{c}\text { Stem diameter } \\
(\mathbf{m m})\end{array}$ \\
\hline $2014-2015$ & $2.35 \pm 0.6 \mathrm{a}$ & $4.54 \pm 0.3 \mathrm{a}$ & $2.41 \pm 0.1 \mathrm{a}$ & $72 \pm 5.1 \mathrm{a}$ & $5.50 \pm 2.6 \mathrm{a}$ \\
$2015-2016$ & $2.51 \pm 0.2 \mathrm{a}$ & $5.40 \pm 0.7 \mathrm{a}$ & $2.59 \pm 0.1 \mathrm{a}$ & $61 \pm 4.2 \mathrm{a}$ & $5.62 \pm 1.7 \mathrm{a}$ \\
\hline
\end{tabular}

(* Naked panicle)

\section{Biomass partition and harvest index (HI)}

Aerial biomass accumulation during both cropping cycles was nearly $90 \%$. No statistical differences $(p \leq 0.05)$ in seeds, stems and roots biomass in both cycles were detected. However, a significant difference in naked panicle (panicle without seeds) weights was noticed (Table 2). Naked panicle comprises the central axis and also secondary and tertiary branches with pedicels. It is interesting to point out that seed and naked panicle weights were similar and then the investments of biomass by the plant becomes similar to produce both usefull seeds and useless panicle waste. In this sense, panicle waste probably could be used as renewable fuel. The harvest index (HI) is another important biomass parameter to assess the dry matter partitioning and efficiency of the plant to mobilizate photoassimilates (Maliro et al., 2017). In both cropping cycles, HI values of the Titicaca cultivar were close to 0.3 (Table 2). Values of HI reported for this cultivar grown in other places were: 0.40 to 0.41 in Italy, 0.38 in Turkey and 0.32 to 0.56 in Malawi (Pulvento et al., 2012; Kir and Temel, 2016; Maliro et al., 2017). Similar values of HI were also communicated for other long cycles quinoa varieties. For example, 0.30 and 0.34 for Faro (sea level cultivar) and Cochabamba (highland cultivar) (Erley et al., 2005). However, Bertero and Ruiz (2008) studying four sea level varieties (NL-6, RU-5, $\mathrm{CO}-407$ and Faro) demonstrated that $\mathrm{HI}$ is a function of plant density. They reported values of 0.40 and 0.30 for the variety NL- 6 growing at a density of 33 and $66 \mathrm{plant} / \mathrm{m}^{2}$, respectively. These authors also reported a $\mathrm{HI}$ mean of 0.26 for all varieties assayed at above mentioned plant densities. However, a wide range of variation of $\mathrm{HI}$ values (from 0.23 to 0.37 ) has been reported for wild quinoa genotypes from dry valleys and highlands growing in the Argentina Northwest (Curti et al., 2014). According with HI values of the Titicaca cultivar grown at Encalilla site can be concluded that it has a high efficiency in the ability of dry matter partition.

Table 2. Biomass and harvest index (HI) of the Titicaca cultivar corresponding to 2014-2015 and 20152016 cropping cycles. Data are means \pm SE of 15 different plants. Means followed by the same letter within a column are not significantly different at $\mathrm{p} \leq 0.05$.

\begin{tabular}{lllrrc}
\hline Cropping cycle & Seeds (\%) & Bracts (\%) & Roots (\%) & Stems (\%) & HI \\
\hline $2014-2015$ & $27.7 \pm 2.6 \mathrm{a}$ & $25.9 \pm 3.6 \mathrm{a}$ & $11.1 \pm 0.6 \mathrm{a}$ & $35.3 \pm 0.6 \mathrm{a}$ & $0.31 \pm 0.01 \mathrm{a}$ \\
$2015-2016$ & $25.2 \pm 1.4 \mathrm{a}$ & $30.2 \pm 2.7 \mathrm{~b}$ & $9.5 \pm 1.1 \mathrm{a}$ & $35.2 \pm 1.6 \mathrm{a}$ & $0.30 \pm 0.01 \mathrm{a}$ \\
\hline
\end{tabular}

\section{Gas exchange parameters}

Under light and $\mathrm{CO}_{2}$ saturating conditions $\left(1500 \mu \mathrm{mol} \mathrm{m} \mathrm{m}^{-2} \mathrm{~s}^{-1}\right.$ and $\left.400 \mu \mathrm{mol} \mathrm{mol} \mathrm{m}^{-1}\right)$ the maximal photosynthetic rate $\left(\mathrm{A}_{\max }\right)$ recorded for Titicaca was $31.3 \mu \mathrm{mol} \mathrm{m}^{-2} \mathrm{~s}^{-1}$ while stomatal conductance $\left(\mathrm{g}_{\mathrm{s}}\right)$ was $0.53 \mathrm{~mol} \mathrm{~m}^{-2} \mathrm{~s}^{-1}$. No data of gas exchange parameters for Titicaca cultivar grown in South America are available and this is the first report concerning gas exchange parameters of Titicaca cultivar, for this we compared the previously obtained results for other quinoa cultivars grown at the Encalilla site (González et al., 2010, 2014). The $\mathrm{A}_{\max }$ obtained was high if we consider the value for some long growth 
cycles varieties as CICA, Ratuqui and Robura (see Table 3 ). In addition, Titicaca $\mathrm{A}_{\max }$ was higher than those other varieties such as CO-407 and Samaranti $\left(15.3 \mu \mathrm{mol} \mathrm{m} \mathrm{m}^{-2} \mathrm{~s}^{-1}\right)$ (Table 3). The $\mathrm{g}_{\mathrm{s}}$ data for Titicaca was higher than the value obtained in field in Denmark $\left(0.23 \mathrm{~mol} \mathrm{~m}^{-2} \mathrm{~s}^{-1}\right)$ (Razzaghi et al., 2015) but close to CICA cultivar but different to those of Robura, Ratuqui and CO-407 cultivars grown (Table 3). For trials under controlled conditions values of $g_{s}$ ranging between 0.24 to $0.85 \mathrm{~mol} \mathrm{~m}^{-2} \mathrm{~s}^{-1}$ were also communicated (Adolf et al., 2012; Yang et al., 2016). The $\mathrm{C}_{\mathrm{i}}$ value was $255.1 \mu \mathrm{mol} \mathrm{CO}_{2} \mathrm{~mol}^{-}$ ${ }^{1}$ which was similar to mean value of $273 \mu \mathrm{mol} \mathrm{CO} \mathrm{Col}^{-1}$ reported for ten quinoa varieties (González et al., 2010) while the maximum carboxylation capacity $\left(\mathrm{A}_{\max } / \mathrm{C}_{\mathrm{i}}\right)$ of Titicaca variety was $122.7 \mathrm{mmol}$ $\mathrm{m}^{-2} \mathrm{~s}^{-1}$, higher than the value of $108.1 \mathrm{mmol} \mathrm{m}^{-2} \mathrm{~s}^{-1}$ reported for the same cultivar grown in Denmark (Razzaghi et al., 2015) and close to highland quinoa varieties (González et al., 2010, 2014). The transpiration rate (E) measured in Encalilla site was near 2-fold higher than Robura Ratuqui and CICA values (Table 3), and near 3-fold higher compared with CO-407 value. Intrinsic water-use efficiency (iWUE) value of the Titicaca cultivar was intermediate regarding to values of comparative cultivars (Table 3).

Table 3. Maximum assimilation rate $\left(\mathrm{A}_{\max }\right)$, stomatal conductance $\left(\mathrm{g}_{\mathrm{s}}\right)$, internal $\mathrm{CO}_{2}$ concentration $\left(\mathrm{C}_{\mathrm{i}}\right)$, transpiration rate $(\mathrm{E})$, maximum carboxylation capacity $\left(\mathrm{A}_{\max } / \mathrm{C}_{\mathrm{i}}\right)$ and intrinsic water-use efficiency (iWUE), of the Titicaca cultivar. Data are means $\pm \mathrm{SE}$ of 5 different plants.

\begin{tabular}{|c|c|c|c|c|c|c|}
\hline & 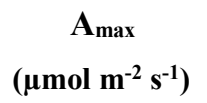 & $\begin{array}{c}\mathbf{g}_{\mathrm{s}} \\
\left(\mathrm{mol} \mathrm{m}^{-2} \mathbf{s}^{-1}\right)\end{array}$ & 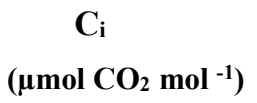 & 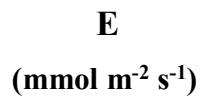 & 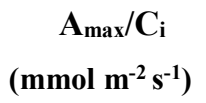 & $\begin{array}{c}\text { iWUA } \\
\left(\mu \mathrm{mol} \mathrm{mol}^{-1}\right)\end{array}$ \\
\hline Titicaca & $31.3 \pm 3.3$ & $0.53 \pm 0.08$ & $255.1 \pm 8.3$ & $10.7 \pm 1.4$ & $122.7 \pm 1.5$ & $59.1 \pm 5.9$ \\
\hline Robura* & $35.1 \pm 2.3$ & $0.42 \pm 0.04$ & $280.0 \pm 15$ & $5.8 \pm 0.5$ & $125.4 \pm 7.1$ & $83.6 \pm 7.2$ \\
\hline Ratuqui* & $30.4 \pm 2.6$ & $0.75 \pm 0.05$ & $270.0 \pm 17$ & $6.5 \pm 0.4$ & $126.3 \pm 9.6$ & $45.5 \pm 3.7$ \\
\hline CICA* & $30.9 \pm 3.2$ & $0.63 \pm 0.05$ & $265.0 \pm 14$ & $6.0 \pm 0.5$ & $116.6 \pm 3.8$ & $49.0 \pm 4.1$ \\
\hline Samaranti* & $15.3 \pm 1.1$ & $0.18 \pm 0.03$ & $270.0 \pm 16$ & $3.0 \pm 0.6$ & $54.81 \pm 5.1$ & $87.1 \pm 6.3$ \\
\hline $\mathrm{CO}-407^{* *}$ & $19.0 \pm 2.5$ & $0.17 \pm 0.04$ & $188.1 \pm 18$ & $3.7 \pm 0.9$ & $101.0 \pm 6.1$ & $111.8 \pm 3.5$ \\
\hline
\end{tabular}

(*) Data from González et al. (2010);

(**) Data from González et al. (2014).

$\mathrm{A}_{\mathrm{n}}$ and $\mathrm{g}_{\mathrm{s}}$ exhibited a significant correlation $\left(r^{2}=0.95, p \leq 0.01\right)$ with a typical hyperbolic relationship which indicated that $A_{n}$ was mainly limited by $g_{s}$ decline (Fig. 1A). Similar relationships between $A_{n}$ and $g_{s}$ were also observed for other quínoa varieties (González et al., 2010) and other field-grown plant species (Centritto et al., 2009). Significant correlations were also observed for the pairs $\mathrm{C}_{\mathrm{i}}$ and $\mathrm{g}_{\mathrm{s}}\left(r^{2}=\right.$ $0.95, p \leq 0.01)$, and $\mathrm{E}$ with $\mathrm{g}_{\mathrm{s}}\left(r^{2}=0.98, p \leq 0.01\right)$ (Fig. 1B and C). These results could indicate that the stomatal play a key role in $\mathrm{CO}_{2} / \mathrm{H}_{2} \mathrm{O}$ gas exchange in the Titicaca variety; however, we did not determine the mesophyll conductance $\left(g_{m}\right)$ and then we can not fully confirm this assumption. All data presented herein are the first time for Titicaca not only for Argentine country but also for S. América.

\section{Ligh-response curve}

The light saturation point (LSP) of the Titicaca cultivar was found to be $1099.3 \mu \mathrm{mol} \mathrm{m}^{-2} \mathrm{~s}^{-1}$ (Table 4, Fig. 2). A close similar value for LSP $\left(1,149.4 \mu \mathrm{mol} \mathrm{m}^{-2} \mathrm{~s}^{-1}\right)$ was found for the Hualhuas variety (Eisa et al., 2012), while values lower than $800 \mu \mathrm{mol} \mathrm{m}^{-2} \mathrm{~s}^{-1}$ were also reported for the same $C$. quinoa cultivar (Geissler et al., 2015). In relation to the light compensation point (LCP) the Titicaca cultivar exhibited a value of $31.3 \mu \mathrm{mol} \mathrm{m}^{-2} \mathrm{~s}^{-1}$ whereas, for the Hualhuas variety values of 20.8 and 28.4 $\mu \mathrm{mol} \mathrm{m} \mathrm{m}^{-2} \mathrm{~s}^{-1}$ were reported (Geissler et al., 2015; Eisa et al., 2012). It is interesting to point out that LCP values o quina cultivars seem to be higher than those reported for other sun leaves, often ranging between 10 and $20 \mu \mathrm{mol} \mathrm{m}^{-2} \mathrm{~s}^{-1}$ (Lemos Filho and Duarte, 1998). The quantum yield of photosynthetic $\mathrm{CO}_{2}$ assimilation $\left(\Phi_{\mathrm{CO} 2}\right)$, which represents the efficiency of absorbed light to fix $\mathrm{CO}_{2}$, was $0.054 \mu \mathrm{mol}$ $\mathrm{CO}_{2} \mu \mathrm{mol}$ photons ${ }^{-1}$. This value was higher than those reported for 10 quinoa cultivars grown at the Encalilla site (González et al., 2010), but lower than that reported for the Hualhuas variety (Geissler et al., 2015). The $\left(\Phi_{\mathrm{CO} 2}\right)$ value found for the Titicaca cultivar was slightly lower than that mean value reported for $\mathrm{C}_{4}$ species and slightly higher for the mean value reported for $\mathrm{C}_{3}$ species (Skillman, 2008). Although $0.125 \mu \mathrm{mol} \mathrm{CO} 2 \mu \mathrm{mol}$ photons ${ }^{-1}$ corresponds to the theoric value of 8 photons required to reduce 1 mole of $\mathrm{CO}_{2}$ in absence of the photorespiration, values higher than 0.07 are rarely observed in 
natural conditions (Skillman, 2008). On the other hand, dark respiration rate $\left(\mathrm{R}_{\mathrm{d}}\right)$ for the Titicaca cultivar was $-2.03 \mu \mathrm{mol} \mathrm{m} \mathrm{m}^{-2} \mathrm{~s}^{-1}$ (negative sign indicates a negative balance between fixed and released $\mathrm{CO}_{2}$ ). Despite that $\mathrm{R}_{\mathrm{d}}$ value reported here was significantly higher than the value of $-4.57 \mu \mathrm{mol} \mathrm{m} \mathrm{m}^{-2} \mathrm{~s}^{-1}$ communicated for the Hualhuas variety (Eisa et al., 2012), it was slightly higher than those reported for sun leaves (Lombardini et al., 2009).

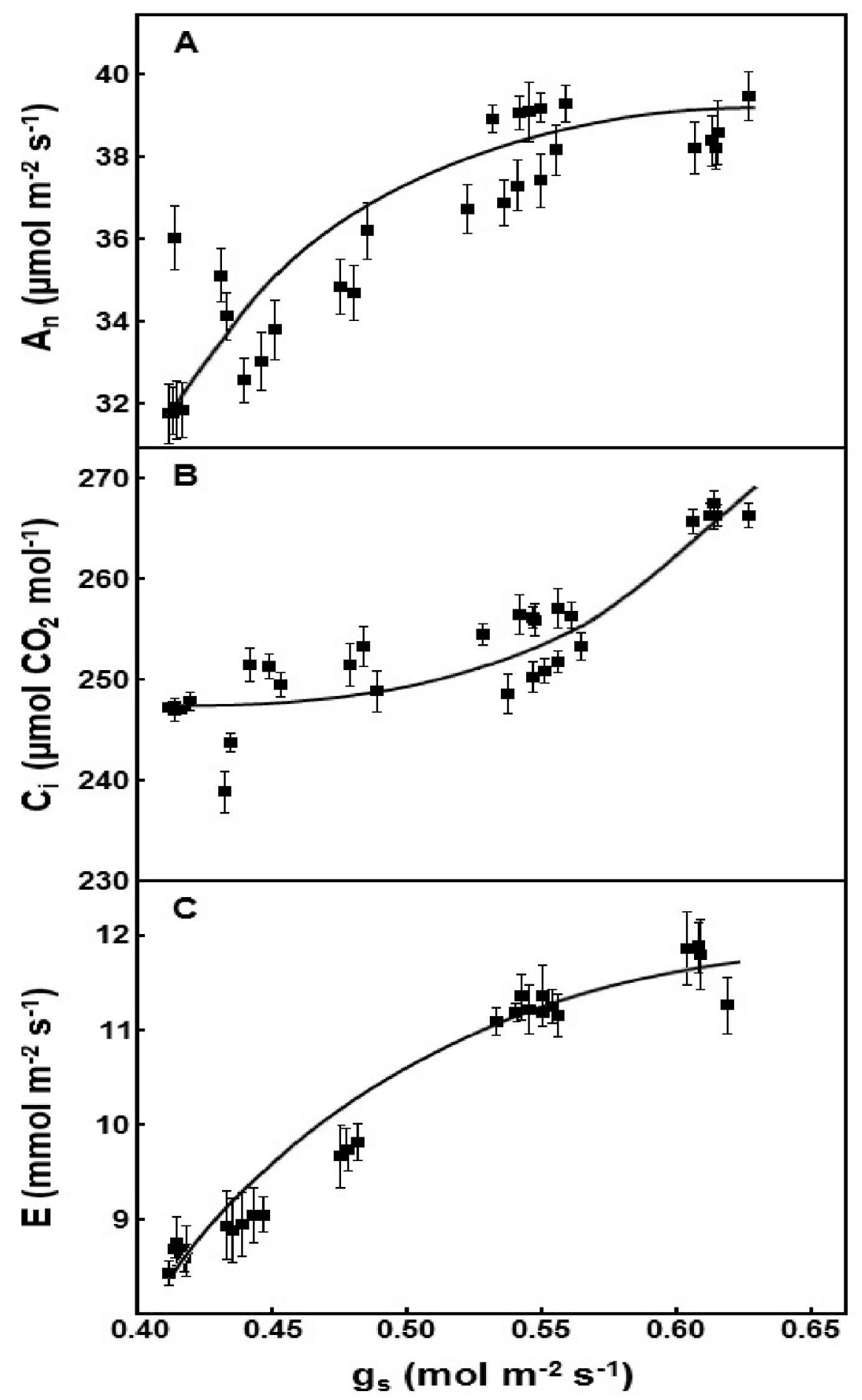

Fig. 1. Relationships between $A_{n}$ and $g_{s}(A) ; C_{i}$ and $g_{s}(B) ; E$ and $g_{s}(C)$ of the Titicaca cultivar. Each point is the mean $\pm \mathrm{SE}$ of 4 independent measurements. Vertical bars indicate SE.

$\mathrm{A}_{\mathrm{n}}=39.54-\left(\exp \left(-14.31 * \mathrm{~g}_{\mathrm{s}}\right)\right) * 2876.60 ; r^{2}=0.94 p \leq 0.01$

$\mathrm{C}_{\mathrm{i}}=368.21-551.73 * \mathrm{~g}_{\mathrm{s}}+626.9 * \mathrm{~g}_{\mathrm{s}}{ }^{2} ; r^{2}=0.95 p \leq 0.01$

$\mathrm{E}=-18.32+98.81 * \mathrm{~g}_{\mathrm{s}}-81.59 * \mathrm{~g}_{\mathrm{s}}{ }^{2} ; r^{2}=0.98 p \leq 0.01$ 
Table 4: Quantum yield of photosynthetic $\mathrm{CO}_{2}$ assimilation $\left(\Phi_{\mathrm{CO} 2}\right)$, dark respiration $\left(\mathrm{R}_{\mathrm{d}}\right)$, light saturation point (LSP) and light compensation point (LCP). Data are means \pm SE of 5 different plants.

\begin{tabular}{|c|c|c|c|}
\hline $\begin{array}{c}\Phi_{\mathrm{CO} 2} \\
\left(\mu \mathrm{mol} \mathrm{CO}_{2} \mu \mathrm{mol}^{-1}\right)\end{array}$ & 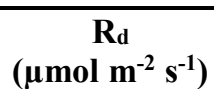 & $\begin{array}{c}\text { LSP } \\
\left(\mu \mathrm{mol} \mathrm{m}^{-2} \mathbf{s}^{-1}\right)\end{array}$ & 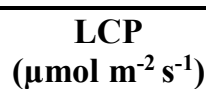 \\
\hline $0.054 \pm 0.015$ & $-2.0 \pm 0.6$ & $1099.3 \pm 170.4$ & $31.3 \pm 3.1$ \\
\hline
\end{tabular}

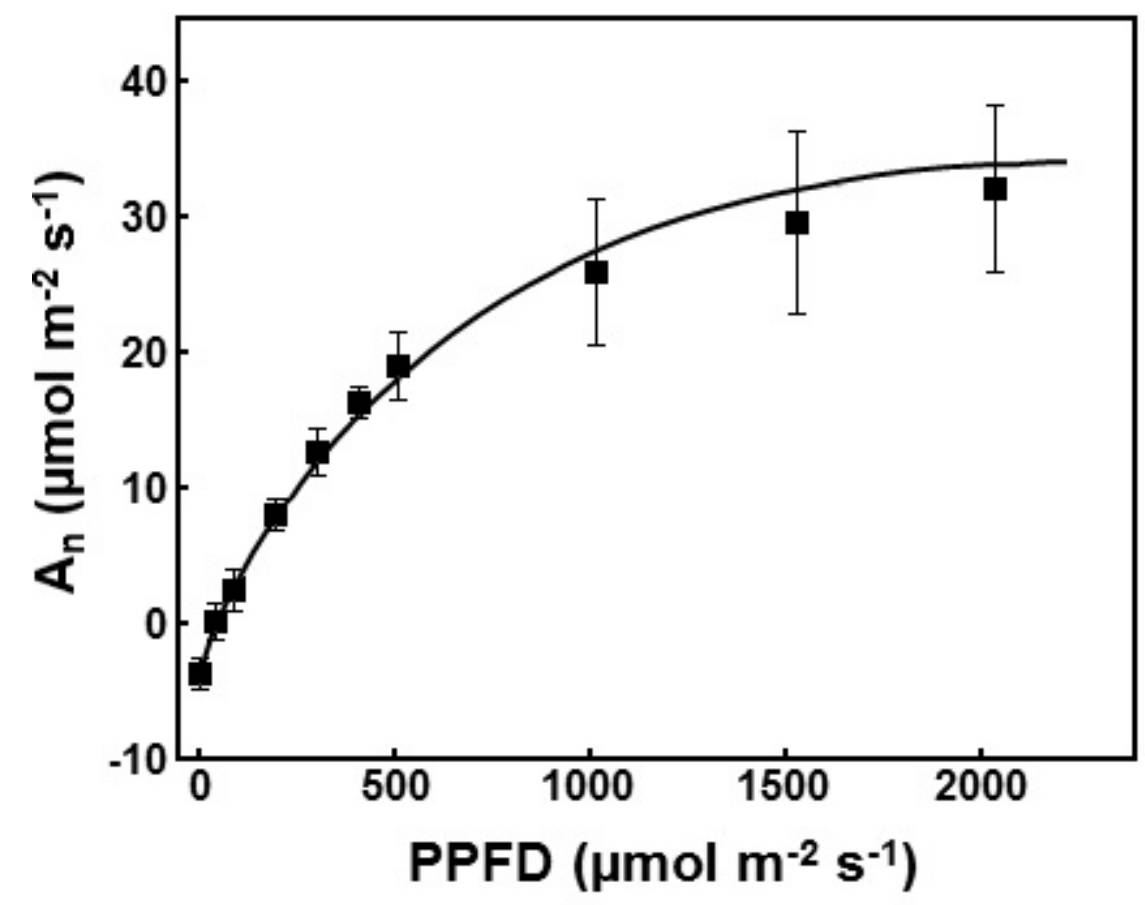

Fig. 2: Net $\mathrm{CO}_{2}$ assimilation rate $\left(\mathrm{A}_{\mathrm{n}}\right)$ as a function of the photosynthetic photon flux density (PPFD). Each point is the mean $\pm \mathrm{SE}$ of 4 independent measurements. Vertical bars indicate SE. $\mathrm{A}_{\mathrm{n}}=35.39-(\exp (-0.0015 * \mathrm{PPFD})) * 37.61 ; r^{2}=0.98 p \leq 0.01$

\section{$\mathrm{A} / \mathbf{C}_{\mathbf{i}}$ curve}

The responses of $A_{n}$ and ETR to $C_{i}$ in the leaves of Titicaca cultivar showed typical photosynthetic characteristics of $\mathrm{C}_{3}$ plants; initially increased and then leveled off at saturating $\mathrm{CO}_{2}$ concentration (Fig. 3). Net photosynthesis $\left(\mathrm{A}_{\mathrm{n}}\right)$ was linearly correlated with internal $\mathrm{CO}_{2}$ concentration $\left(\mathrm{C}_{\mathrm{i}}\right)$ ranging from 62 to $210 \mu \mathrm{mol} \mathrm{CO} \mathrm{Col}^{-1}$. The slope of the $\mathrm{A}_{\mathrm{n}} / \mathrm{C}_{\mathrm{i}}$ curve that corresponds to the carboxylation efficiency (CE) was $0.241 \mu \mathrm{mol} \mathrm{m}^{-2} \mathrm{~s}^{-1}$. The compensation point (CP) was $68.8 \mu \mathrm{mol}$ $\mathrm{CO}_{2} \mathrm{~mol}^{-1}$. In a similar way, ETR was linearly correlated with $\mathrm{C}_{\mathrm{i}}$ ranging from 150 to $250 \mu \mathrm{mol} \mathrm{CO}_{2}$ $\mathrm{mol}^{-1}$. Both $\mathrm{A}_{\mathrm{n}}$ and ETR were saturated beyond $482.4 \mu \mathrm{mol} \mathrm{CO}_{2} \mathrm{~mol}^{-1}\left(\mathrm{~A}_{\mathrm{n}}=43.03 \mu \mathrm{mol} \mathrm{m}^{-2} \mathrm{~s}^{-1}\right)$ and at $250 \mu \mathrm{mol} \mathrm{CO} \mathrm{m}^{-1}\left(\mathrm{ETR}=205.5 \mu \mathrm{mol} \mathrm{m} \mathrm{m}^{-2} \mathrm{~s}^{-1}\right)$, respectively. Similarly, $\mathrm{A}_{\mathrm{n}}$ and ETR were curvilinearly correlated with internal $\mathrm{CO}_{2}$ concentration $\left(\mathrm{C}_{\mathrm{i}}\right)$. Under saturating PPFD $\left(1500 \mu \mathrm{mol} \mathrm{m}^{-2} \mathrm{~s}^{-1}\right)$ the stomatal conductance $\left(\mathrm{g}_{\mathrm{s}}\right)$ was sensitive to $\left(\mathrm{C}_{\mathrm{i}}\right)$ with a non-linear decline of near $42 \%$ when $\mathrm{C}_{\mathrm{i}}$ was increased (Fig. 4). Although non-linear responses of $g_{s}$ to $C_{i}$ have been frequently reported in $C_{3}$ species, linear responses were also communicated (Düring, 2003). In fact, differences in the response of $g_{s}$ to $C_{i}$ in species with similar photosynthetic pathway indicate different stomatal responses to ambient level of $\mathrm{CO}_{2}$. 


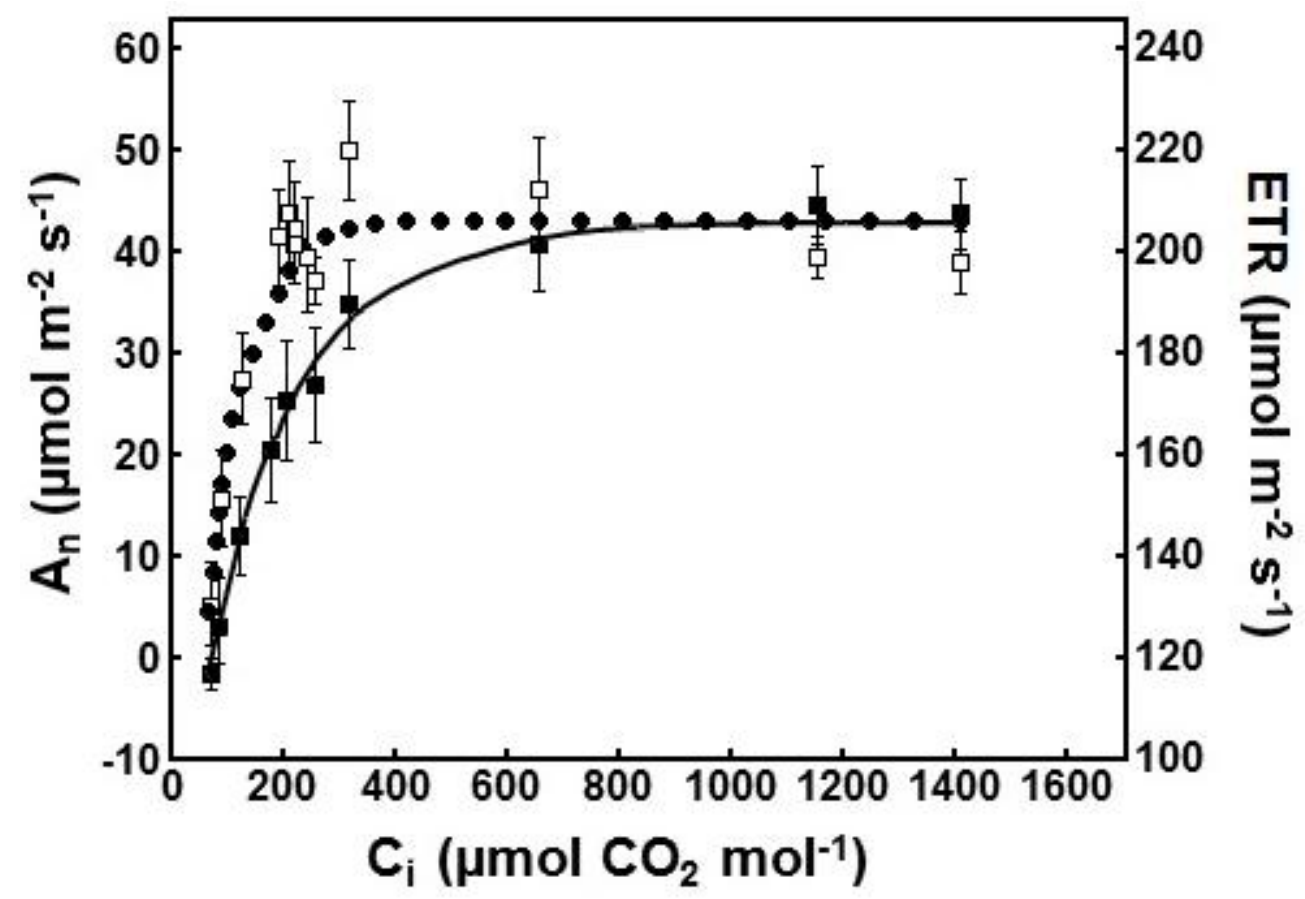

Fig. 3: Net $\mathrm{CO}_{2}$ assimilation rate $\left(\mathrm{A}_{\mathrm{n}}\right)$ and electron transport rate (ETR) as a function of intercellular $\mathrm{CO}_{2}$ concentration $\left(\mathrm{C}_{\mathrm{i}}\right)$ in leaves of the Titicaca cultivar at $1500 \mu \mathrm{mol} \mathrm{m} \mathrm{m}^{-2} \mathrm{~s}^{-1}$ PPFD. Each point is the mean $\pm \mathrm{SE}$ of 4 independent measurements. Vertical bars indicate SE.

(*) $\mathrm{An}=43.03-\left(\exp \left(-0.0057 * \mathrm{C}_{\mathrm{i}}\right)\right) * 62.90 ; r^{2}=0.98 p \leq 0.01$

$(\bullet) \mathrm{ETR}=205.49-\left(\exp \left(-0.0179 * \mathrm{C}_{\mathrm{i}}\right)\right) * 229.95 ; r^{2}=0.96 p \leq 0.01$

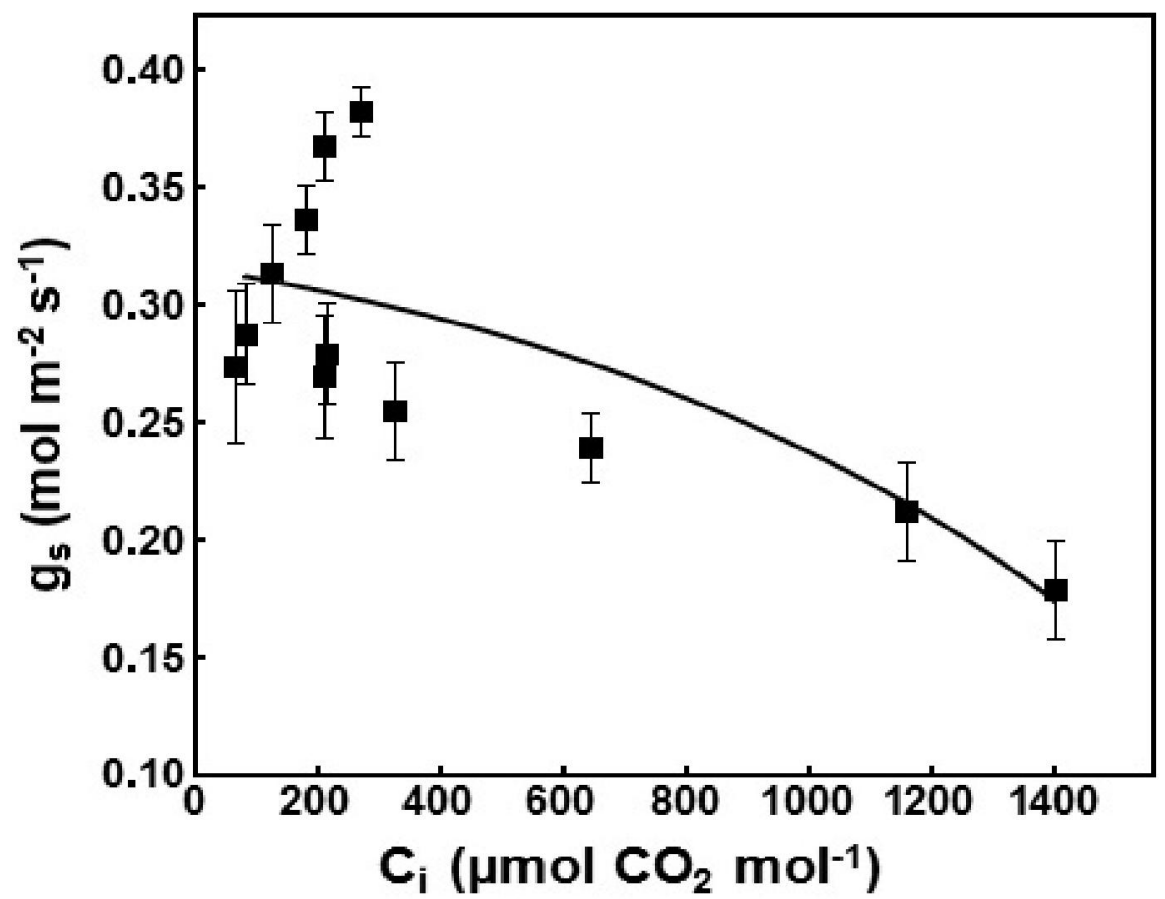

Fig. 4. Stomatal conductance $\left(g_{s}\right)$ in response to intercellular $\mathrm{CO}_{2}$ concentration $\left(\mathrm{C}_{\mathrm{i}}\right)$ in leaves of the Titicaca cultivar at $1500 \mu \mathrm{mol} \mathrm{m} \mathrm{m}^{-2} \mathrm{~s}^{-1}$ PPFD. Each point is the mean \pm SE of 4 independent measurements. Vertical bars indicate SE.

$\mathrm{g}_{\mathrm{s}}=0.3121-3.28 \times 10^{-5} * \mathrm{C}_{\mathrm{i}}-4.67 \times 10^{-8} \mathrm{C}_{\mathrm{i}}^{2} ; r^{2}=0.73 p \leq 0.01$ 


\section{Photosynthetic and UV-B absorbing pigments}

Chlorophyll content, carotenoids and UV-B absorbing pigments in Titicaca leaves is shown in Table 5. Chlorophyll concentration was $3.25 \mathrm{mg} \mathrm{g}^{-1} \mathrm{DW}$ which was either similar or lower than reported for other quinoa cultivars. Thus, González et al. $(2010,2014)$ reported that total chlorophyll contents ranged from 2.98 to $11 \mathrm{mg} \mathrm{g}^{-1} \mathrm{DW}$ for 12 quinoa cultivars from the Peruvian and Bolivian Altiplano grown at the Encalilla site. Similarly, carotenoid concentration in the Titicaca cultivar $\left(0.36 \mathrm{mg} \mathrm{g}^{-1} \mathrm{DW}\right)$ was lower than those reported by other quinoa cultivars (González et al., 2010, 2014). It is notwithstanding that Titicaca leaves exhibited a high content of UV-B absorbing pigments $\left(0.46 \mathrm{~A}_{305}\right.$ $\left.\mathrm{g}^{-1} \mathrm{DW}\right)$. It is noteworthy that available data on the concentration of photosynthetic and UV protective pigments in quinoa varieties are very variable (Gonzalez et al., 2010, 2014). It is not known if this trait can be related to environmental differences of the origin sites of cultivars (Fuentes et al., 2009). According to this hypotheis low values of both chlorophyll and carotenoid pigments measured in Titicaca leaves may be related to an adaptation process of this cultivar to lower value of solar irradiance in Denmark. Whilst, the highest concentration of UV-B absorbing pigments found in the Titicaca cultivar growing in the Encalilla site probably can be related to early gene expression related to the synthesis of phenolic compounds (e.g. flavonoids, lignin) to protect the photosynthetic machinery (Hilal et al., 2004). Supporting our assumption, it has been well demonstrated that quinoa cultivars exhibit higher adaptation plasticity to different light environments (González et al., 2009).

Table 5: Chlorophyll $a(\mathrm{Chl} a)$, chlorophyll $b(\mathrm{Chl} b)$, Total chlorophyll [Chl $(a+b)]$, Chl $a / \mathrm{Chl} b$ ratio, carotenoids (Car.), and UV-B absorbing pigments in leaves of Titicaca cultivar. Values are mean \pm SE of 5 different plants.

\begin{tabular}{cccccc}
\hline $\begin{array}{c}\text { Chl } \boldsymbol{a} \\
(\mathbf{m g} / \mathbf{g} \text { DW) }\end{array}$ & $\begin{array}{c}\text { Chl } \boldsymbol{b} \\
(\mathbf{m g} / \mathbf{g ~ D W})\end{array}$ & $\begin{array}{c}\text { Chl }(\boldsymbol{a}+\boldsymbol{b}) \\
(\mathbf{m g} / \mathbf{g} \text { DW) }\end{array}$ & Chl $\boldsymbol{a} / \mathbf{C h l} \boldsymbol{b}$ & $\begin{array}{c}\text { Car. } \\
(\mathbf{m g} / \mathbf{g} \text { DW })\end{array}$ & A $305 / \mathbf{g}$ DW \\
\hline $2.21 \pm 0.3$ & $1.05 \pm 0.06$ & $3.25 \pm 0.4$ & $2.10 \pm 0.23$ & $0.36 \pm 0.03$ & $0.46 \pm 0.05$ \\
\hline
\end{tabular}

\section{Conclusion}

This article reports the main results of the research activities carried out for the first time for evaluation of a promising new cultivar of quinoa developed in Denmark (Titicaca variety). The study presents the grain yield and photosynthetic characterization of the Titicaca cultivar in the Argentinean Northwest region of South America. Crop cycles in 2015 and 2016 years were 95-100 days. Grain yield, harvest index and physiological parameters suggest a good adaptation of the Titicaca cultivar to high mountain valleys of the Argentina Northwest.

\section{Acknowledgements}

This work was supported by Fundación Miguel Lillo (Miguel Lillo 251, T4000JFE, Tucumán, Argentina) under the Project B-0004-1 ("Ecophysiology of selected varieties of quinoa and others species with nutritional values in lab and field"). Our thanks goes to Carlos Segura (Campo Experimental de Encalilla - INTA - Amaicha del Valle) ) who help in field measurements in both 2014/2015 and 2015/2016 cropping cycles.

\section{References}

Adolf, V.I., S. Shabala, M.N. Andersen, F. Razzaghi and S.E. Jacobsen, 2012. Varietal differences of quinoa's tolerance to saline conditions. Plant Soil, 357: 117-129.

Bertero, H.D. and R.A. Ruiz, 2008. Determination of seed number in sea level quinoa (Chenopodium quinoa Willd.) cultivars. Euro. J. Agronomy, 28: 186-194.

Batjes, N.H. 1997. A world dataset of derived soil properties by FAO-UNESCO soil unit for global modelling. Soil Use Manage 13:9-16. 
Bazile, D. and D. Baudron, 2015. The Dynamics of the Global Expansion of Quinoa Growing in View of its High Biodiversity. In: Bazile, D., D. Bertero \& C. Nieto (Eds.), State of the Art Report of Quinoa in the World in 2013. pp. 42-55. FAO \& CIRAD, Rome.

Centritto, M., M. Lauteri, M.V. Monteverdi and R. Serraj. 2009. Leaf gas exchange, carbon isotope discrimination, and grain yield in contrasting rice genotypes subjected to water deficits during the reproductive stage. J. Exp. Bot. 60:2325-2339.

Chapelle, E.W., M.S. Kim and J.E. Mcmurtrey III. 1992. Ratio analysis of reflectance spectra (RARS): an algorithm for the remote estimation of the concentrations of chlorophyll $a$, chlorophyll $b$, and carotenoids in soybean leaves. Remote Sens Environ 39:239-247.

Christiansen, J.L., S.E. Jacobsen and S.T. Jørgensen. 2010. Photoperiodic effect on flowering and seed development in quinoa (Chenopodium quinoa Willd.). Acta Agric. Scand. 60:539-544.

Curti, R.N., A.J. De La Vega, A.J. Andrade, S.J. Bramardi and H.D. Bertero. 2014. Multi-environmental evaluation for grain yield and its physiological determinants of quinoa genotypes across Northwest Argentina. Field Crops Res. 166:46-57.

Delgado, P.A.I., C.J.H. Palacios and G.C. Betancourt. 2009. Evaluation of 16 genotypes of sweet quinoa (Chenopodium quinoa Willd.) in the municipality of Iles, Nariño (Colombia). Agron. Colomb. 27:159-167 (in spanish).

Duncan, D.B. 1955. Multiple range and multiple F-test. Biometrics 11: 1-42.

Düring, H. 2003. Stomatal and mesophyll conductances control $\mathrm{CO}_{2}$ transfer to chloroplasts in leaves of grapevine (Vitis vinifera L.). Vitis 42:65-68.

Eisa, S., S. Hussin, N. Geissler and H.W. Koyro. 2012. Effect of $\mathrm{NaCl}$ salinity on water relations, photosynthesis and chemical composition of quinoa (Chenopodium quinoa Willd.) as a potential cash crop halophyte. Aust J Crop Sci. 6:357-368.

Erley, G.S., H.P. Kaul, M. Kruse and W. Aufhammerb. 2005. Yield and nitrogen utilization efficiency of the pseudocereals amaranth, quinoa, and buckwheat under differing nitrogen fertilization. Eur. J. Agron. 22:95-100.

Farquhar, G.D. and T.D. Sharkey. 1982. Stomatal conductance and photosynthesis. Annu Rev Plant Physiol 33:317-345.

Fuentes, F.F., P.J. Maughan and E.R. Jellen. 2009. Genetic diveersity and genetic resources for quinoa (Chenopodium quinoa Willd) improvement. Revista Geográfica de Valparaíso 42: 20-33 (in spanish).

Geissler, N., S. Hussin, M.M. El-Far and H.W. Koyro. 2015. Elevated atmospheric $\mathrm{CO}_{2}$ concentration leads to different salt resistance mechanisms in a $\mathrm{C} 3$ (Chenopodium quinoa) and a $\mathrm{C} 4$ (Atriplex nummularia) halophyte. Environ. Exp. Bot. 118:67-77.

Genty, B., J.M. Briantis and N.R. Baker. 1989. The relationship between the quantum yield of photosynthetic electron transport and quenching of chlorophyll fluorescence. Biochim. Biophys. Acta 990:87-92.

Gómez-Pando, L.R., R. Alvarez-Castro and A. Eguiluz-De la Barra. 2010. Effect of salt stress on peruvian germplasm of Chenopodium quinoa Willd: A promising crop. J. Agron. Crop Sci. 196:391-396.

González, J.A., m. Bruno, M. Valoy and F.E. Prado. 2010. Genotypic variation of gas exchange parameters and leaf stable carbon and nitrogen isotopes in ten quinoa cultivars grown under drought. J. Agron. Crop Sci. 197:81-93.

González, J.A., S. Eisa, S. Hussin and F.E. Prado. 2015. Quinoa: an Inca Crop to face Global Changes in Agriculture. In: Murphy, K.S., Matanguihan, J. (Eds.), Quinoa: Improvement and Sustainable Production. pp. 1-18. Wiley-Blackwell, Hoboken, NJ, USA. 
González, JA., Y. Konishi, M. Bruno, M. Valoy and F.E. Prado. 2011. Interrelationships among seed yield, total protein and amino acid composition of ten quinoa (Chenopodium quinoa) cultivars from two different agroecological regions. J. Sci Food Agric. 92:1222

González, J.A., G.I. Ponessa, S.E. Buedo, M.I. Mercado and F.E. Prado. 2014. Maximum photosynthetic assimilation in quinoa varieties (Chenopodium quinoa) from different geographic origins, and its relation to leaf morphology. Lilloa 51:177-193 (in spanish).

González, J.A., M. Rosa, M., M.F. Parrado, M. Hilal and F.E. Prado. 2009. Morphological and physiological responses of two varieties of a highland species (Chenopodium quinoa Willd.) growing under near-ambient and strongly reduced solar UV-B in a lowland location. $J$. Photochem Photobiol B. 96: 144-151.

Gulzar, S., M.A. Khan, I.A. Ungar X. and Liu. 2005. Influence of salinity on growth and osmotic relations of Sporobolus ioclados. Pak. J. Bot. 37:119-129.

Hilal, M., M.F. Parrado, M. Rosa, M. Gallardo, E.M. Massa, J.A. González, and F.E. Prado. 2004. Epidermal lignin deposition in quinoa cotyledons in response to UV-B radiation. Photochem Photobiol 79:205-210.

Jacobsen, S.E. 2003. The worldwide potential for quinoa (Chenopodium quinoa Willd.). Food Rev Int 19:167-177.

Jacobsen, S.E. 2015. Adaptation and Scope for Quinoa in Northern Latitudes of Europe, In: Bazile, D., D. Bertero and C. Nieto (Eds.), State of the Art Report of Quinoa in the World in 2013. pp. 436446. FAO \& CIRAD, Rome

Jacobsen, S.E., J.L. Christiansen and J. Rasmussen. 2010. Weed harrowing and inter-row hoeing in organic grown quinoa (Chenopodium quinoa Willd.). Outlook on Agriculture 39: 223-227.

Jacobsen, S.E., M. Sørensen, S.M. Pedersen and J. Weiner. 2013. Feeding the world: genetically modified crops versus agricultural biodiversity. Agron. Sustain. Dev. 33:651-662.

Kir, A.E. and S. Temel. 2016. Determination of seed yield and some agronomical characteristics of different quinoa (Chenopodium quinoa Willd.) variety and populations under dry conditions of Igdir plain. Iğdır Univ. J. Inst. Sci. \& Tech. 6:145-154.

Lavini, A., C. Pulvento, R. D’andria, M. Riccardi, R. Choukr-Allah, O. Benlhabib, A. Yazar, ç. Incekaya, S. Metin Sezen, M. Qadir and S.E. Jacobsen. 2014. Quinoa's potential in the Mediterranean region. J. Agron. Crop Sci. 200:344-360.

Lemos Filho, J.P. and R.J. Duarte. 1998. Seed reserves partition and light compensation point of Mahogany (Swietenia macrophylla King.) seedlings growth under low photosynthetic active radiation. Braz. arch. biol. technol. 41: 207-211.

Lombardini, L., H. Restrepo-Diaz and A. Volderolder . 2009. Photosynthetic light response and epidermal characteristics of sun and shade pecan leaves. J. Amer. Soc. Hort. Sci. 134:372-378.

Maliro, M.F.A., V.F. Guwela, J. Nyaika and K.M. Murphy. 2017. Preliminary studies of the performance of quinoa (Chenopodium quinoa Willd.) genotypes under irrigated and rainfed conditions of Central Malawi. Front. Plant Sci. 8:1-9.

Mirecki, R. and A.H. Teramura. 1984. Effects of ultraviolet-B irradiance on soybean. V. The dependence of plant sensitivity on the photosynthetic photon flux density during and after leaf expansion. Plant Physiol. 74:475-480.

Pulvento, C., M. Riccardi, A. Lavini, G. Lafelice, E. Marconi and R. D'andria. 2012. Yield and quality characteristics of quinoa grown in open field under different saline and non-saline irrigation regimes. J. Agron. Crop Sci. 198:254-263.

Rawson, H.M., J.E. Begg and R.G. Woodward. 1977. The effect of atmospheric humidity on photosynthesis, transpiration and water use efficiency of leaves of several plant species. Planta 134:5-10. 
Razzaghi, F., S.L. Jacobsen, C.R. Jensen and M.N. Andersen. 2015. Ionic and photosynthetic homeostasis in quinoa challenged by salinity and drought mechanisms of tolerance. Funct. Plant Biol. 42:136-148.

Repo-Carrasco, R., C. Espinoza, C. and S.E. Jacobsen. 2003. Nutritional value and use of the Andean crops quinoa (Chenopodium quinoa) and kañiwa (Chenopodium pallidicaule). Food Rev. Int. 19: 179-189.

Rojas, W., M. Pinto, C. Alanoca, L. Gómez Pando, P. León Lobos, A. Alercia, S. Diulgheroff, S. Padulosi and Bazile, D. 2015. Quinoa Genetic Resources and ex Situ Conservation. In: Bazile, D. Bertero, D., Nieto, C. (Eds.), State of the Art Report of Quinoa in the World in 2013. pp. 5682.FAO and CIRAD, Rome.

Schreiber, U., U. Schliwa and W. Bilger. 1986. Continous recording of photochemical and nonphotochemical chlorophyll fluorescence quenching with a new type of modulation fluorometer. Photosynth. Res. 10: 51-62.

Schulte, M., C. Offer and U. Hansen. 2003. Induction of $\mathrm{CO}_{2}$-gas exchange and electron transport: comparison of dynamic and steady-state responses in Fagus sylvatica leaves. Trees 17: 153-163.

Shams, A.S., 2012. Response of Quinoa to Nitrogen Fertilizer Rates Under Sandy Soil Conditions. Proc. $13^{\text {th }}$ International Agronomy Conference. Faculty of Agriculture, Benha University, Egypt, pp. 195-205.

Skillman, J.B., 2008. Quantum yield variation across the three pathways of photosynthesis: not yet out of the dark. J. Exp. Bot. 59:1647-1661.

Van Wart. J., K.C. Kersebaum, S. Peng, M. Milner and K.G. Cassman. 2013. Estimating crop yield potential at regional to national scales. Field Crops Res. 143: 34-43.

Wellburn, A.R. 1994. The spectral determination of chlorophylls $a$ and $b$, as well as total carotenoids, using various solvents with spectrophotometers of different resolution. J. Plant Physiol. 144: 307313.

Yang, A. Z., S.S. Akhtar, S. Iqbal, M. Amjad, M. Naveed, Z.A. Zahir and S.E. Jacobsen. 2016. Enhancing salt tolerance in quinoa by halotolerant bacterial inoculation. Funct. Plant Biol. 43: 632-642.

Yazar, A., S.M. Sezen, S. Tekin and Ç. Incekaya. 2016. Quinoa: from experimentation to production in Turkey. International Quinoa Conference: Quinoa for Future Food and Nutrition Security in Marginal Environments, FAO, Dubai, p. 10. 